OPEN ACCESS

Edited by:

Andrea M. Feldpausch-Parker, State University of New York College of Environmental Science and Forestry, United States

Reviewed by: Ann Grand University of Exeter, United Kingdom Jen Schneider, Boise State University, United States

${ }^{*}$ Correspondence: Jason Chilvers jason.chilvers@uea.ac.uk

Specialty section: This article was submitted to Science and Environmental

Communication,

a section of the journal Frontiers in Communication

Received: 13 November 2017 Accepted: 20 March 2018 Published: 13 April 2018

Citation:

Chilvers $J$ and Pallett H (2018) Energy Democracies and Publics in the Making: A Relational Agenda for Research and Practice.

Front. Commun. 3:14. doi: 10.3389/fcomm.2018.00014

\section{Energy Democracies and Publics in the Making: A Relational Agenda for Research and Practice}

\author{
Jason Chilvers* and Helen Pallett \\ Science, Society and Sustainability (3S) Research Group, School of Environmental Sciences, University of East Anglia, \\ Norwich, United Kingdom
}

Mainstream approaches to energy democracy and public engagement with energy transitions tend to adopt specific, pre-given meanings of both "democracy" and "publics." Different approaches impose prescriptive assumptions about the model of participation, the identity of public participants, and what it means to participate well. The rigidity of many existing approaches to energy participation is increasingly being challenged by the ever-multiplying diversity of ways in which citizens participate in energy systems, as consumers in energy markets, protesters against new infrastructures and technologies, as initiators of community energy projects, and as subjects of behavior change interventions, amongst others. This paper is concerned with growing areas of scholarship which seek to understand and explore these emerging energy publics and forms of energy democracy from a relational perspective. Such work, grounded in constructivist and relational ontologies, views forms of participatory democracy and publics as being co-produced, constructed, and emergent through the performance of collective practices. It pays closer attention to power relations, politics, materiality, exclusions, and effects in both understanding and intervening in the making of energy democracy. This in turn shifts the focus from studying discrete unitary forms of "energy democracy" to one of understanding interrelations between multiple diverse energy democracies in wider systems. In this paper, we chart these developments and explore the significant challenges and potential contributions of relational approaches to furthering the theories, methods, and practices of energy democracy and energy public engagement. The paper draws on an expert workshop, and an accompanying review, which brought together leading proponents of contending relational approaches to energy participation in direct conversation for the first time. We use this as a basis to explore tensions between these approaches and set out a relational agenda for energy democracy research in terms of: developing concepts and theories; methodological and empirical challenges; and implications for practices of governance and democratic engagement with energy transitions.

Keywords: energy democracy, public engagement, relational, emergent, co-productionist 


\section{INTRODUCTION}

It is not so long ago that centralized energy systems developed by industrialized nation states through the twentieth century seemingly left little role for the public, other than as "passive consumers," removed from the governance, materials, and infrastructures of energy production and supply (Walker and Cass, 2007). However, the past two decades have witnessed thoroughgoing changes in the relationship between energy systems and their publics. Transformations in how energy is governed and produced, including the neoliberalization of energy markets and the rise of more distributed forms of energy production and renewables, have multiplied the roles that publics can and do take up in relation to energy (Devine-Wright, 2007). In addition, the looming energy crisis that accompanied the dawn of the twenty-first century-whether defined in terms of the "energy trilemma" of global climate change, energy security and socio-economic inequalities (Hammond and Pearson, 2013) or some more complex entanglement of issues that make up this very "political situation" (Barry, 2012)-means that publics are now simultaneously sought out, implicated in, and actively seek out their place in energy transitions. What publics think, know, say and do has become an important concern of energy research, government policy, corporate strategy, and social movements.

Though discussions around the importance of energy transitions have multiplied in policymaking and in the academic literature (Araújo, 2014), these discussions have neglected the social and political dimensions of transitions (Miller et al., 2013, 2015) and leave little role for citizens or democratic processes (Hendriks, 2009; Laird, 2013). Calls have been made for social scientists to more fully conceptualize and demonstrate the range of existing and potential forms of citizen participation in determining and enacting energy transitions, as part of the project of democratizing these processes and holding decisionmakers to account (Stirling, 2014). Of course, citizens frequently figure in a wide range of government interventions and areas of the academic literature including consultation processes, opinion polls, behavior change programmes, social marketing campaigns, social media, planning protests, activism and public demonstrations, lobbying, investment decisions, the co-design of energy technologies, participatory energy modeling, visioning exercises, open innovation processes, citizen science, hacker spaces, smart energy technologies, eco-homes, community energy schemes, other grassroots energy innovations, and others (on this diversity, see for example Chilvers and Longhurst, 2012).

However, in this paper we argue that the majority of these approaches and ways of describing energy democracy and participation assume a fixed, pre-given and "residual realist" view of the public and of democratic engagement. Following Chilvers and Kearnes (2016a), what we mean by residual realist here is that the who (i.e., public participants) and how (i.e., models of participation and democracy) of energy democracy are viewed in a realist sense as being highly specific, pre-given, external, and naturally occurring categories. This upholds a dominant perspective and imaginary whereby many existing approaches prescribe a narrow definition of energy democracy and participation to the exclusion of others. The emphasis is on developing and "scaling up" democratic and participatory procedures, and judging them against externally prescribed principles and evaluative criteria, that fit within a pre-given normativity of democracy and participation.

There are many examples of mainstream approaches that adopt relatively fixed, pre-given meanings of what it means to participate in this way, and imagine involvement occurring in discrete events or cases in particular parts of wider energy systems. Take for instance public opinion research and deliberative democratic procedures. The emphasis here is on establishing public views, and achieving equitable and competent public group deliberation, on choices and decisions about energy system transitions (e.g., Burgess and Chilvers, 2006; Stagl, 2006; Hendriks, 2009; Pidgeon et al., 2014). Such appoaches tend to involve "general" or lay publics often in interaction with "experts," are judged in terms criteria like representaitiveness, inclusivity, and impact on decision-making, and are often called upon to seek "public acceptance" of energy policies and technologies. Contrast this with attempts to engage publics in changing their energy behaviors (e.g., Abrahamse et al., 2005), which tend to center on the workplace, the home and efforts to reduce energy demand, and are evaluated against criteria such as energy savings and carbon reduction. In other areas of research and practice, studies of social movements and transitions management approaches, respectively, hone in on energy democratic engagement in the form of public protest or activism (e.g., Saunders and Price, 2009) and sites of community mobilization and grassroots innovation (e.g., Seyfang et al., 2013). For these modes of energy democracy the focus is more on resisting or assisting system change, whether in terms of technological innovation or more radical social change.

Each of these approaches adopt specific pre-given meanings of energy participation and democratic engagement, to the exclusion of others. They each attend to particular parts of wider energy systems in comparmentalized ways. They place an emphasis on doing energy democracy through developing methods and procedures, rather than posing more critical and reflexive questions about power relations, politics, and exclusions that work through these processes. When it comes to evaluation, it is the positive effects and impacts of participation that are emphasized and looked for, not the negative effects and downsides. These aspects, associated with a residual realist imaginary of energy participation, can actually limit the ability of energy democracy initiatives to address the systemic, complex, and long-term nature of energy transitions in equitable, inclusive, and socially responsive ways (see Chilvers and Longhurst, 2016).

This can also be seen in the nascent but emerging writing on energy democracy. While the notion of energy democracy that has recently emerged in social movements and radical scholarship (Kunze and Becker, 2014) has been largely ill-defined, most sources emphasize bottom-up, civic and communitybased empowerment, ownership, and/or control over energy production and consumption (e.g., Morris and Jungjohann, 2016; Burke and Stephens, 2017; Fairchild and Weinrub, 2017). Becker and Naumann (2017) have sought further clarification by suggesting a typology that classifies energy democracy projects into those that emphasize: decentralized energy provision; 
collective ownership of energy services; or energy sovereignty over resources. Szulecki's (2018) recent attempt to bring further definitional clarity expands the frame to also include prosumer action, but ultimately offers an evaluation and "decision-making tool" based on indicators to judge energy democracy along the three dimensions of popular sovereignty, participatory governance, and civic ownership. Barring a few exceptions (e.g., Hess, 2018; Van Veelen, 2018) then, most existing writings on energy democracy adopt a residual realist standpoint, emphasizing particular definitions and normativities of energy democracy to the exclusion of others, and prescribing universal pre-given evaluative principles and criteria external to the situated performance and construction of energy democracy in practice.

More relational approaches in science and technology studies (STS), geography and cognate disciplines have attempted to account for the ways in which different forms of energy democracy and their publics are made, constructed, and coproduced. These studies illustrate the range of ways in which citizens are already participating within and against energy transitions, as community energy cooperatives (e.g., Yildiz et al., 2015), activists (e.g., North, 2011), participants in invited deliberative processes (e.g., Soneryd, 2016), and as energy users in the home (e.g., Shove et al., 2012) including their interaction with material devices (e.g., Marres, 2011). Such work, grounded in constructivist and relational ontologies, views forms of participatory democracy and publics as being co-produced, constructed, and emergent through the performance of collective practices. It pays closer attention to power relations, politics, materiality, exclusions, and effects in both understanding and intervening in the making of energy democracy. This shifts the focus from studying discrete unitary forms of "energy democracy" to one of understanding multiple diverse energy democracies which intermingle in wider systems. However, relational approaches are emerging from different disciplinary standpoints, with competing understandings and assumptions about what brings energy democracy and publics into being, and with what effects. In addition, relational approaches have thus far attended to discrete case study examples of public engagement with energy and focused on particular modes of democratic engagement. There has been little cross-comparative work aiming to draw wider lessons about emerging energy publics in diverse forms and locations. There is a need to look across a broader range of modes of energy democracy and the making of energy publics, to reflect their diversity but also to identify more general patterns, stabilities, and shifts in the role of citizens in energy transitions.

In order to address these issues this paper is informed by an expert workshop, held in April 2014, which brought together leading proponents of contending relational approaches to the making of energy participation and publics in direct conversation for the first time (further details of the workshop format and participants are provided in Chilvers and Pallett, 2015). The workshop aimed to consider the potential academic and practical value, across a range of different approaches, of adopting a perspective on energy publics as relational and coproduced. The 1-day workshop involved presentations drawing across contending relational approaches before opening up to discussion where workshop participants considered what it would mean to take seriously and properly account for emerging publics and forms of democratic engagement in and around energy systems. Through exploring the similarities and differences of emerging relational approaches the workshop considered the implications for theory, modes of study, and practices of energy participation. Workshop discussion was analyzed through qualitative coding which produced key themes presented in a workshop report (see Chilvers and Pallett, 2015). This helped frame a comprehensive review of the academic literature which forms the basis of this paper.

Many relational and constructivist studies of energy participation emanate from STS and human geography, which forms the interdisciplinary focus of this paper, alongside cognate disciplines in the energy social sciences and humanities. While overlaps exist between STS scholarship and the emerging subfield of energy communication (Endres et al., 2016; Cozen et al., 2018), we move beyond the frame of the latter by taking a relational starting point and by considering a wider diversity of energy democracy-related practices within which forms of energy communication exist. In what follows, we first contextualize our argument by reviewing dominant perspectives on energy public engagement in the literature. Here, we contrast "residual realist" understandings of energy publics, found in much of the academic and gray literature, with constructivist and relational perspectives from the interpretive social sciences which present a view of energy publics as emerging rather than pre-given. We argue that these relational approaches can be further enhanced with a co-productionist perspective which would enable more symmetrical and comparative analyses between different kinds of energy public engagement and conceptual frames. In the remainder of the paper we set out a relational agenda for energy democracy research in terms of: developing concepts and theories; methodological and empirical challenges; and implications for practices of governance and democratic engagement with energy transitions.

\section{ENERGY DEMOCRACIES AND PUBLICS IN THE MAKING}

Until recently, core energy research has tended to neglect the social dimensions of energy systems, with social science and interdisciplinary approaches being under-represented (see Sovacool, 2014). Miller et al. (2015) identify a neglect of social dimensions in energy policy discussions more broadly, and in the design of key governing institutions. Of course, government policy around the energy system does engage with social dimensions and energy publics in an increasing diversity of ways, though these are heavily shaped by assumptions coming from economics and behavioral psychology. Citizens are engaged as consumers of energy through market mechanisms and social marketing projects (Dolan et al., 2012), and are also increasingly seen as community groups who could be recruited for community energy generation and behavior-change projects (Owens and Driffill, 2008). The rising interest in policy 
circles in the concept of "Big Data" and the possibility of accumulating large data sets from social media and government services, also recasts citizens as sources of information about new trends or potential challenges and controversies (Jasanoff, 2017). A small but significant set of approaches to engaging citizens with policy-making concerns two-way dialogue in the form of deliberative public engagement exercises. These have been carried out, for example, by the UK Government-funded programme Sciencewise and the Danish Board of Technology, around topics including acceptability of particular energy technologies, or how greenhouse gas reduction targets might be met (Mohr et al., 2013; Pallett and Chilvers, 2013).

However, what these diverse approaches have in common is they often assume a particular fixed model of democratic engagement and imagine an external public existing in a natural state waiting to be revealed, engaged, or mobilized by science and democracy (Chilvers and Kearnes, 2016a). This way of understanding energy democracy and its publics as static and pre-given is even reflected by approaches which advocate more interactive forms of engagement influenced by deliberative democratic theory, in that they are based on an implicit model of (consensual) democratic engagement which assumes a particular kind of citizen who will act in a certain way (cf. Hendriks, 2009). Understandings of forms of democratic engagement and publics as fixed entities have been challenged by constructivist theories in STS, geography, political/democratic theory, and anthropology (e.g., Irwin and Michael, 2003; Irwin, 2006; Lezaun and Soneryd, 2007; Bennett, 2009; Mahony et al., 2010; Marres and Lezaun, 2011; Chilvers and Kearnes, 2016a). Such work sees publics as actively brought into being by the very ways actors seek to know and move them-whether that be through practices of opinion polling, behavior change, protest movements, or grassroots community innovations, for example. Any understanding of engagement practices, publics, their knowledges, and actions, thus cannot be separated from the ways in which they are mediated and configured in particular settings.

While relational approaches vary, a common central argument is that most existing ways of knowing, doing, and governing energy publics fail to properly account for how publics and engagement practices are actively constructed and shaped byand in turn shape-the various material settings, technologies, infrastructures, issues, participatory procedures, and political philosophies with which they are associated. Rather than existing as fixed entities waiting to be discovered, energy publics are seen to be co-produced through the mutual constitution of social, political, and technical orders (Jasanoff, 2004), in the performance of participatory experiments and practices at particular sites (Laurent, 2011; Chilvers and Longhurst, 2016), and the more durable relations between citizens, technoscience, and the state held together in wider assemblages, institutions, and political cultures (Jasanoff, 2011).

Owens and Driffill (2008) identify the normative and autocratic assumption, evident in much government engagement with publics on energy issues, that public attitudes and behaviors need to be changed. Furthermore, they criticize the persistent assumption that attitudes and behaviors can be straightforwardly altered through communication and engagement, drawing on critiques from STS of "deficit model" assumptions (Wynne, 1991) and sociological research which reveals a more complex relationship between attitudes and behaviors (Blake, 1999). Social practice theorists have further challenged the behavior change agenda by criticizing the assumption that publics behave as individual rational actors. Theorists like Shove et al. (2012) have suggested that individuals or the public as a whole are not an appropriate focus for study, instead advocating an emphasis on energy-related practices themselves.

A related set of relational approaches coming from human geography, sociology, and STS have further interrogated the relational nature of publics, highlighting the multifaceted and contingent conditions implicated in their emergence. Work specifically concerned with renewable energy technologies and siting (Walker and Cass, 2007; Barnett et al., 2010; Walker et al., 2010; Cotton and Devine-Wright, 2012) has demonstrated the strong role played by imaginaries of or assumptions about energy publics in the construction of public engagement around renewable energy. Such studies argue that certain publics are performatively brought into being by strongly held models and assumptions, like that of NIMBYism which presupposes opposition from narrow motivations. Contributions from relational STS have described the mutual construction of particular kinds of energy publics and issues/objects of interest. For example, Noortje Marres work has demonstrated the important role played by material technologies in the smart home (Marres, 2012) and understandings of particular policy issues (Marres, 2007) in mediating and transforming energy publics. Similarly, Barry's (2013) work on the Baku-TbilisiCeyhan pipeline illustrates how different kinds of publics emerge at different times and places alongside different manifestations of policy issues and the "political situation."

Research on diverse emerging public engagements with energy abounds, though with contrasting conceptual approaches and terminologies. As with recent developments in energy communication (Endres et al., 2016), this is moving beyond a focus of high-level controversies to consider more mundane and distributed engagements with energy in everyday life (Michael, 2016). As demonstrated above, studies of social movements, active communities, deliberative democratic engagement, energy users in the home and more could be considered as relational accounts. However, this nascent literature remains fragmented, with different sets of approaches tending to focus on particular parts of the energy system, adopting particular concepts of what it means to participate, and working with particular kinds of partners and publics. The lack of connections and conversations in particular between approaches focused on behavior change vs. those emphasizing public acceptance of energy policies and technologies, even where similar concepts and methodologies are used, has also been noted (Owens and Driffill, 2008; Marres, 2012). This fragmentation leads to a further concern, that the partiality of these necessarily situated accounts is not fully acknowledged or reflected on, and that connections between different publics or broader developments in energy systems are not fully understood. Therefore, we advocate a more coproductionist, symmetrical, and comparative approach to the study emerging forms of democratic engagement and energy 
publics, which is able to draw from a shared conceptual framework and talk about developments at the national scale and beyond. Only then can the diversity and contingency of emerging forms of energy democracy and their publics be accounted for. The remainder of this paper explores the opportunities and challenges of adopting such an approach.

\section{A RELATIONAL AGENDA FOR ENERGY DEMOCRACY RESEARCH AND PRACTICE}

\section{Relational Concepts and Theories}

Even amongst the literature offering relational accounts of energy participation, there are several different concepts and theoretical frameworks used to explain the making and mediation of energy publics. These different approaches variously emphasize or deemphasize the relative roles played by social practices and procedures, material objects and issue-framings, imaginaries, and forms of human agency in the making of energy publics. Though they are not necessarily mutually exclusive or in competition with one another, these different emphases shape analyses in contrasting ways with potential implications for methods of empirical study and practices of governance and engagement (as discussed in the sections on Methodological and Empirical Challenges and Governance and Engagement Practice below). Furthermore, these conceptual approaches are rarely brought into direct conversation with one another, as we attempt to do in this section.

One strand of scholarship foregrounds the role of objects in shaping publics, including material energy technologies and infrastructures, and different expressions or framings of the issue in question. Noortje Marres (2012) has looked at the role played by devices in an eco-show home in processes of participation, embodying assumptions about energy itself and the publics or users to be engaged. Goulden et al. (2014) make similar arguments with regards to visions of future smart grids in energy scenarios, showing how different visions can variously conjure energy citizens or energy consumers, with different expected behaviors and permissible roles. Marres (2007) has also argued that the framing of particular (energy) issues dictates the nature and form of public involvement possible around that issue, thereby shaping energy publics. Cowell (2010) has made a similar argument in the context of wind energy planning decisions in Wales by exploring the highly contingent processes by which "acceptable locations" for wind energy were identified and constructed within the national assembly, limiting the forms of participation and the potential participants in planning decisions.

At the level of particular energy landscapes, Barry (2013) has explored the emergence and management of different energy publics around the Baku-Tbilisi-Ceyhan oil pipeline in conjunction with a number of different but connected "political situations" encompassing material elements such as landslides or the pipeline itself. Similarly Krauss (2010) has examined the wind power landscapes of North Frisia and Dithmarschen in Germany, offering rich ethnographic observations of the emergence of particular kinds of publics and modes of democratic engagement often in the intersections between wind energy and other land use controversies in the area. At a macro level Winner's (1986) classic study of the politics of artifacts argued that nuclear power was "socially constituted" in terms of a centrally controlled energy system, shaping energy publics (cf. Grove-White et al., 2006).

In a second strand of scholarship exploring emerging energy publics authors have emphasized the role played by procedural "technologies of democracy" and forms of participatory expertise (Chilvers, 2008) in knowing and mobilizing energy publics. Lezaun and Soneryd (2007) have explored the rise of "technologies of elicitation" for involving citizens in decisions around energy and other topics, arguing that they presuppose, and bring into being particular publics - usually those with no prior knowledge of or position on the issue under discussion. This approach has also been used to examine how these particular technologies of participation travel between different policy and national contexts, being interpreted differently and interacting with pre-existing publics and constitutional stabilities (Soneryd, 2016). Bauer and Pregernig (2013) have used a similar approach when looking at techniques of technology assessment and foresight around energy, arguing that the design and underlying assumptions of these procedures influence the selection and interactions of participants. This approach has the scope not only to explore deliberative democratic technologies of participation, but could also be applied to other techniques such as opinion polls or public attitudes surveys, or even forms of protest and activism; all of which make assumptions about the public which is to be engaged and contribute to the emergence of energy publics through their design and framing. For example, Jones et al. (2013) reveal the highly contingent way in which so-called "nudge" techniques of behavioral economics have developed, with implications for the kinds of citizens who are engaged and brought into being. Furthermore, Asdal and Marres (2014) suggest that social science methods themselves assume and bring into being certain kinds of publics.

Concerned more with the sphere of human action and agency, a third set of approaches that seek to understand the construction of societal engagement with energy has foregrounded everyday energy-related social practices-like thermal comfort, showering, and cooking-as central to configuring everyday public life around energy (Shove, 1998; Shove et al., 2012; Hargreaves, 2013). In challenging economistic and psychological behavior change approaches, social practice theorists have decentered the conventional focus on individual energy consumers, or even on energy publics, instead taking social practices themselves as the focus of study. In this literature so far, therefore, central questions have not concerned the making of energy participation and publics but rather the related processes by which particular social practices become stabilized or might change over time with implications for energy systems. Energy publics in this sense are groups of practitioners associated with a potentially large range of energy-related practices, though social practice theory studies have until recently focussed primarily on domestic energy-related practices.

The raw power of human action in mediating public engagements with energy has been emphasized in a fourth set of approaches to understanding emerging energy publics, whether that be the power of facilitators, mediators, and 
community organizers (Elam et al., 2007; Chilvers, 2008), the force of social movements (Seyfang and Haxeltine, 2012), or incumbent institutions (Stirling, 2008). In her in-depth ethnography around a wind energy project in a village in East Frisia, Northern Germany, Carlson (2014) explores complex community dynamics and patterns of engagement and disenfranchisement woven through everyday village life mediated by particular individuals and institutional structures. Pacheco et al. (2014) explore the co-emergence of social movements around wind energy with the industry itself and associated institutions, arguing that there is strong evidence of mutual influence between these three bodies. Many authors have emphasized the role played by institutions in shaping energy publics, for example exploring the strength of old technocratic modes of governing in shaping modes of engagement and ways of interpreting public responses, even where governing institutions are attempting to be open and consultative (Kim, 2014). Another strong shaping force has been the focus on progress in science and technology as a primary driver of economic productivity, a foundational assumption which governing institutions often put before and allow to shape other forms of energy public engagement (Bowness and Hudson, 2014; Stirling, 2014).

Others have focussed on the constrained ways in which opportunities for public involvement in democratic decisionmaking are framed, limiting the kinds of views and people who can be involved, and the potential of the process to influence decision-making (Lee et al., 2012). A significant focus in studies of this kind has been on the institutional assumptions made about energy publics themselves, influencing how they are engaged and interpreted. For example, in the context of formal "invited" public engagement processes Wynne (2006b) and others have pointed out the continual projection of deficit-model visions of the public by governing institutions, assuming that public dissent, opposition, and disinterest is down to deficits in public understanding of the issue, or public trust, rather than engaging with the politics of the issue under debate. Similarly, in the context of planning decisions related to wind energy generation. Bristow et al. (2012) have explored the very specific way in which "communities" are imagined, with implications for how they are engaged around these decisions and who is eligible to receive community benefits.

Lastly, some scholars have highlighted the importance of narratives, visions, and imaginaries of energy systems and futures that are durable over space and time, being continually (re)produced through the performances of state decision making and distributed energy publics. The notion of socio-technical imaginaries, developed by Jasanoff and Kim, has been used to understand the relationship between particular visions of future energy systems-and by implication particular visions of energy publics and forms of democracy-and the design of particular energy-related scientific and technological projects including nuclear power (Jasanoff and Kim, 2009), the German "Energiewende" (Jasanoff and Kim, 2013), bioenergy (Eaton et al., 2014), through to more distributed and localized energy imaginaries (Smith and Tidwell, 2016). The idea of stories and story-telling as modes of making energy publics has also recently been developed in several energy-related projects, including the
"Energy Biographies" project which has developed longitudinal stories of changes in individual's energy-related practices in a variety of different locations (Butler et al., 2014; Shirani et al., 2015).

Contending relational approaches to understanding democracy and publics in the making outlined above have broader implications for how social scientists, policy actors, and others theorize and conceptualize public engagement in energy transitions. Different relational theories foreground the relative roles of technologies, objects/issues, social practices, procedures, imaginaries, and forms of human action in the making of energy publics. Bringing different approaches into conversation in this way raises questions about the effects of foregrounding these different elements in analyses of energy participation, and to what extent these different theories are complementary, working in tension, or completely incompatible? Our review, and supporting expert workshop analysis (Chilvers and Pallett, 2015), provides the basis to identify four important imperatives for future theoretical and conceptual developments to understand energy democracies and their publics in the making.

1. Understanding energy democracies and their publics as diverse, relational, and co-produced. Despite their differences the relational approaches explored in this section share the perspective that energy democracy and energy publics are not narrowly defined, fixed or pre-given categorieslike "deliberative democracy," "community energy," "energy behavior change," and so on-but are continually being made, constructed, and remade through the performance of socio-material practices. They call for a shift away from thinking that takes energy democracy for granted as a natural or unitary category, to a more agnostic approach that opens up to the sheer diversities of energy democracies that are continually being performed across energy systems and beyond. Relational approaches force us to consider the democratic/anti-democratic possibilities not only of public, deliberative, discursive, or institutional forms of energy participation but also in terms of material, mundane, everyday, and private spaces of public engagement with energy. They call for an increased focus on power, politics and exclusions in the construction of diverse energy publics and how these process are always shaped by wider social, political, and constitutional orders.

2. Valuing difference and symmetry in relational theories of energy participation. It is important to recognize the value of developing alternative relational theories and their relative contributions and implications for studying the dynamics of energy democracies and emergent publics. In seeking to explain how energy democracies and their publics are brought into being there is value in developing theories that allow explanatory emphasis to be variously placed on: emergence and the role of objects and non-humans (in the case of assemblage or actor-network based theories), the role of relational stabilities and already existing powers tied up extant orders, expertise, technologies, imaginaries and other durable elements (such as constitutional co-productionist theory), or a greater emphasis on human agency in the performance of 
practices in situ (as is foregrounded by social practice theory). At the same time there is also a need to develop relational and co-productionist theories that are more symmetrical in the relative emphasis that they place on the roles of objects, formats, and human agency in bringing (energy) democracies and publics into being-retaining conceptual agnosticism to see the variable role of each being foregrounded or backgrounded in different times, places, and sites of public engagement with energy (see for example, Pallett and Chilvers, 2013; Chilvers and Kearnes, 2016b; Chilvers and Longhurst, 2016).

3. Toward conceptualizing systems of energy participation. Thinking relationally and symmetrically about diverse forms of energy participation in these ways prompts a further important area of conceptual development in energy democracy research. This involves moving from thinking about energy participation in terms of discrete isolated cases toward conceiving of multiple practices of energy democracy and public mobilization as intermingling and interrelating in wider systems. In these terms, the dynamics and qualities of energy democracy should be analyzed not in terms of discrete instances of energy democracy but in terms of the performance of multiple forms of democratic engagement and representation occurring across energy systems. Many of the relational theories discussed in this section are undergoing a "systemic turn" that can form part of such conceptual development, including work on systems of practice (Watson, 2012); deliberative systems (Parkinson and Mansbridge, 2012), ecologies of participation (Chilvers and Kearnes, 2016b), and conceptualizing constitutional relations between citizens, science and the state in STS co-productionist scholarship (Jasanoff, 2011). Of course, it is important to be aware that different relational approaches would have different conceptions of the energy system itself and the containers or objects with(in) which diverse energy publics are engaging, ranging from political situations (Barry, 2012), issue spaces (Marres, 2007), institutions (Wynne, 2006b), democratic systems (Owen and Smith, 2015), the nation-state (Jasanoff, 2011), landscapes (Krauss, 2010), complexes of practice (Hui et al., 2016), and so on.

4. Attending to the performativity and situatedness of theory in studies of energy democracy and participation, is a final theoretical necessity that emerges from taking a relational perspective on energy democracies. Relational approaches blur the traditional distinctions between theory, methods, and practice that are maintained in realist approaches to energy participation. This urges theoretical developments to be reflexive about the ways in which theory plays a role in shaping both research methods and actual practice. In this sense, in the energy field one can see a persistent presence of "theory in the wild." For example, policy professionals' understanding of energy publics is often informed by theories from economics and psychology, but also increasingly the role of theories from interpretive social science such as democratic theory or social practice theory. These theories often co-exist in particular settings and also shape the understandings and accounts given by research participants, even before any formal contact with researchers. Theories used to understand energy publics are also performative in how they shape the framings, products, and effects that researchers have. As discussed above in this section, there is a strong association between certain theoretical perspectives, parts of the energy system, the kinds of publics studied, and the actors sought as research users or collaborators. This suggests researchers need to show more awareness and reflection about the ways in which their conceptual resources frame their accounts and interventions. A co-productionist approach would further encourage reflection and awareness of ways in which sociopolitical orders and cultures, as well as the object(s) of energy itself, shape and influence theoretical developments. For example, in workshop discussions (Chilvers and Pallett, 2015) it was observed that many STS theoretical perspectives on the democratization of science and technology emerged out of-and were shaped by-energy-related case studies, objects, and controversies (e.g., Wynne, 1996; Nowotny et al., 2001; Callon et al., 2009).

\section{Methodological and Empirical Challenges}

In this section, we move on to explore the challenges and implications of adopting relational approaches (as set out above) for the methods by which energy publics and practices of energy democracy are studied. It is common in relational accounts of energy publics to distinguish between invited and uninvited publics and between top-down and bottomup, organic and orchestrated, formal and informal modes of engagement. However, such labels are often applied a priori or in a broad-brush manner. Relational theories can often fail to translate into relational methods. This can serve to closedown studies to particular meanings of energy publics and participation to the exclusion of other framings, diversities, and complexities of people's material and affective attachments with energy. Furthermore, the strong shaping of empirical accounts by the conceptual and theoretical approaches chosen (as discussed in the section on Relational Concepts and Theories) often entails making a priori assumptions about these different publics rather than taking an empirically-oriented approach to the realities of energy public engagement. Relational theories pose further challenges around the politics of different forms of academic knowledge-making, urging analysts to consider how social science or humanistic methods are implicated in shaping and creating certain visions and enactments of energy publics.

Interventionist approaches are commonly used in studies of energy public engagement, particularly involving deliberative, co-design, and action-research methodologies. Deliberative methods of public participation have been used extensively both in policy and academic contexts, involving two-way engagement with a small number of participants over a day or more, to gain a rich picture of public views on a given topic. Such methods have been used as part of forecasting and foresight projects (Bauer and Pregernig, 2013), transition management projects (Hendriks, 2009), policy decisions at a number of levels (Burgess and Chilvers, 2006; Cowell, 2010), and assessments of emerging technologies like carbon capture and storage 
(Einsiedel et al., 2013; Lock et al., 2014), or fracking (TNS BMRB, 2014). These approaches often aim to bring together those with different perspectives for example by selecting from contrasting demographic groups, bringing together citizens with experts in energy-related topics (Stagl, 2006), or attempting to bridge divides between different domains of thought and action (Callon et al., 2009). However, they have been criticized for making framing assumptions about their participants, for example limiting their contributions to the domain of values rather than new knowledge (Chilvers and Burgess, 2008) or deliberately seeking out only "innocent citizens" (Irwin, 2001) with no pre-defined interest in or knowledge of the issue under discussion. Some relational accounts have tried to deal with this through using reflexive methodologies which show awareness of these framing effects (Williams et al., 2017), or by deliberately including a more diverse range of participants and triangulating with other methods of engagement (Pidgeon et al., 2014).

Co-design is another interventionist approach which has been adopted in policy and academic contexts to know and bring into being public engagement with energy. Social practice theorists have worked with engineers and household energy practitioners in studying household technologies which may alter, or be altered by, everyday energy practices (Hargreaves et al., 2013; Strengers, 2013). In some cases these projects have adopted a more participatory design, incorporating the ideas and needs of research participants in novel household technologies (ECDC, 2017). Similar projects have been inspired by a more object oriented conceptual focus, most notably speculative design projects which aim to create monitoring or information giving technologies relating to energy that can bring certain kinds of publics into being or empower particular collectives (Gabrys, 2014; Wilkie et al., 2015).

Action-research and participant observation methodologies have been particularly adopted by those studying social movements or protests and working with these conceptual approaches (e.g., Saunders and Price, 2009; North, 2011). These approaches try to acknowledge and account for the normativity of the researcher's positions and interventions, and are often adopted when the researchers have similar beliefs and convictions to the research participants. These methodologies can encompass a wide range of interventions, but what they have in common is that they explicitly set out to record and account for the effects of the researcher's interventions and positions. Therefore, this approach blurs clear distinctions between energy publics and researchers, and highlights the roles played by researchers in both constituting and creating energy publics.

More conventional qualitative methodologies including semistructured interviews and document analysis are associated with a range of different conceptual approaches to understanding energy publics and forms of democracy. For example, they are generally adopted in studies emphasizing human agency in the making of energy publics, from studies exploring the power of mediators of participation processes (Chilvers, 2008) to those emphasizing the importance of institutional cultures and assumptions (Cowell et al., 2011). Such methods have also been used in issue-focussed studies of debates and publics emerging around an object such as fracking, exploring what the discourses at play show about power relations, policy framings, and energy publics (Jaspal and Nerlich, 2014). These methods also form the basis for analysis in studies aiming to identify particular genealogies of participatory and policy practices which make energy publics (Soneryd, 2016), as well as the imaginaries of energy technologies and systems which are co-constructed with energy publics (Jasanoff and Kim, 2013).

These in-depth and historically informed analyses of the making of energy publics are also often the result of archival methods, sometimes combined with long term ethnographic work and involvement around a particular domain (Jones et al., 2013). Long term archival and ethnographic methods are also necessary for studies which aim to provide rich and complex accounts of energy landscapes and their publics (Krauss, 2010; Barry, 2013). This enables these accounts to illustrate the contingencies in the current states of affairs and potentially opens up space for alternative ways of seeing and constructing energy publics.

Interviews, document analysis and more participatory methods have been used by those adopting narrative approaches to emerging energy publics and forms of democratic engagement (e.g., Moezzi et al., 2017; Raven, 2017; Smith et al., 2017). Drawing inspiration from the humanities and other creative disciplines these methods are used to derive stories and narratives which can then be used in a variety of engagements with marginalized or activist communities, as well as with policy-makers and other actors as tools for communication and engagement (Shirani et al., 2015). Stories are both relational and generative so can be used to reflect uncertainties, complexities, and contingencies around energy public engagements, and can potentially account for the multiplicity of perspectives and explanations around emerging energy publics.

Increasingly, a range of digital methods are being used to understand and engage with emerging energy publics, including growing government interest in "crowdsourcing" and "sentiment mapping" using social media platforms. Emerging digital methods and digital humanities approaches (Rogers, 2013; Marres, 2017), more closely based on relational theories, are increasingly being applied to energy issues. This includes issuemapping which draws on social media and other internetbased platforms to map a particular energy-related issuespace or controversy (Marres, 2015). This technique helps to identify the different collectives at play around a given issue-space and provides a basis for understanding their relationships. Importantly, such methods go beyond studies of public involvement with energy in discrete cases or sites to open up to more systemic understandings (as introduced in the section on Relational Concepts and Theories) of how multiple forms of energy participation intermingle in wider systems. Opening up to wider ecologies of participation in this way is has also been achieved through forms of qualitative metaanalysis (Macnaghten and Chilvers, 2014), comparative case analysis (Chilvers and Longhurst, 2016), and systematic reviews (Pallett et al., 2017) to study diverse and interrelating forms of public engagement occurring across wider energy systems and constitutions. 
In this section, we have shown that alongside a considerable diversity of theoretical and conceptual approaches, there is also a wide range of methodological approaches to understanding energy democracy and emerging publics "in the making." Sometimes these methods are closely linked to a particular theoretical perspective, for example the relationship between deliberative theory and interventionist participatory processes or the relationship between action-research methods and social movements theories. While in some cases this relationship is more ambiguous, this illustrates that the choice of method has performative framing effects for the kind of accounts of energy democracy and emerging publics which get produced (cf. Asdal and Marres, 2014). For example, some methods might contribute to an emphasis on historical factors or the role played by individuals in a given account. Furthermore, methods such as deliberative engagement or action-research contain a priori assumptions about the kinds of publics which are being engaged and the correct modes of engagement. Taken as a whole, alongside workshop discussions (Chilvers and Pallett, 2015), the review in this section points to four main areas of questioning for future methodological development and empirical study.

1. The need for situated empirical studies into how practices of energy democracy are constructed, co-produced, and with what effects. Relational perspectives call for an ambitious programme of empirically-oriented studies that explore how instances of energy democracy and energy public mobilization are constructed and get made. Drawing on some of the methods explored in this section, there is a need for such studies to ask how collectives of energy democracy are mediated and orchestrated, how human and non-human actors are enrolled into these processes, and with what exclusions and effects? Such studies can serve to broaden the evaluative frame of "residual realist" accounts of energy participation, which are centered on narrow metrics that assess the positive effects-such as the carbon reduction of behavior change initiatives or the representativeness of deliberative events. Relational empirically-oriented studies can produce more robust evidence by remaining open to the multiple productivities and effects, both good and bad, of instances of energy democracy.

2. Toward more symmetrical studies of the interrelations and entanglements between diverse practices of public engagement with energy. Drawing on the arguments made in the section Relational Concepts and Theories, such studies could adopt the principle of symmetry through a comparative research design, or by exploring the ways in which different theoretical perspectives might engage with the same case study, potentially producing a diversity of accounts and having broader effects which themselves could be monitored. This recognition of the diversity of energy publics which is increasingly evident in energy communication research (Endres et al., 2016), and the related diversity in ways of studying these publics, offers a challenge to conventional casestudy based approaches which are the way in which most interpretive social scientific knowledge about energy publics is produced. To be clear, moving beyond isolated case studies does not mean simply reverting to large-scale quantitative methods or big data analytics that produce an image of a flat, static, amalgamated public. The challenge is to develop systemic, comparative, and symmetrical studies that can retain a sense of the contingencies, contexts, and specificities of diverse practices through which energy democracies and publics are co-produced. Such studies would move from studying energy democracy in terms of isolated case studies, to develop new knowledge about how multiple forms of energy public engagement across wider systems interact and affect the performance of each other.

3. Comparative studies between and across energy democracies, systems and political cultures. The democratization of energy system transitions, as with much energy social science research, often takes a national focus. Relational approaches to energy participation, particularly work in STS, emphasize the need for comparative research between contrasting national political cultures and energy systems to explore how these constitutional arrangements shape (and are shaped by) the performance of energy-related public participation within these settings (cf. Jasanoff and Kim, 2013). Thinking about forms of energy democracy as practices, innovations, and technologies in their own right, as relational STS perspectives urge researchers to do (e.g., Soneryd, 2016), also expands the sites of empirical study to the processes through which and spaces where models of energy democracy circulate translocally between and within nation states, and their impacts on the localities where they are replicated (for example, how particular models of community energy have become replicated within and across countries in Europe).

4. Attend to the performativity of method in studies of energy democracies and their publics. A more relational understanding suggests that in future accounts of energy democracy and energy public engagement it would be a productive and interesting to reflect upon and take account of the potential performative effects of social science methods in shaping what is found out about publics, democracy, and the energy issues in question. Such concerns could even inform the design of studies of energy publics themselves, necessitating the active and reflexive monitoring of these factors (as is further elaborated in the section on Reflexive and Experimental Energy Participation, below).

\section{Governance and Engagement Practice}

Our final area of exploration in this paper is to consider what taking a relational and constructivist perspective on democratic engagement with energy might mean for practices of governing and of public participation in energy transitions. While relational approaches have been developed in theoretical and empirical studies, as outlined in the above sections, such thinking has rarely been translated into policy and practice. Instrumental and residual realist approaches to engaging society with energy dominate mainstream practice. This includes commonly adopted approaches to bring about behavior change, often grounded in the disciplines of psychology and economics, through to approaches that seek public acceptance of energy policies and technologies (such as public attitude surveys and deliberative 
processes). Such approaches tend to take for granted the who (the participating subjects) and the how (the model or format) of democratic engagement with energy, presuming these categories to be fixed and pre-given, rather than actively constructed through the performance of participation. Furthermore, the ways in which these approaches are often performed in energy policy and practice largely upholds a centralized and top-down model of the energy system (Stirling, 2014), whereby realist forms of energy participation are used either explicitly or implicitly to gain public views that feed into decisions made by so called "highlevel" actors in government and industry, or to change public behaviors to bring them into line with dominant policy framings.

Relational co-productionist theories and empirical studies can lead to very different ways of practicing energy democracy and ways in which the qualities of energy participation might be judged. Taking a relational and symmetrical approach to energy public engagement in the making also has implications for how academics, policy-makers, citizens, and other actors understand and might intervene in processes to democratize energy. Both academic accounts and interventions in practice could aim to represent energy publics in ways that pay due attention to the inherent uncertainties, indeterminacies, contingencies, and framing effects of their production. Relational approaches also raise legitimate questions about how relations between science, governance and society would need to be reconfigured to better account for the inherent uncertainties, diversities, materialities, and competing visions of emergent energy publics. However, there is a dearth of work outlining possible ways forward. The agenda we set out in this section is therefore somewhat speculative. We draw on Chilvers and Kearnes's (2016c) relational framework of four paths for remaking participation in science and democracy more broadly as a way of structuring and sensitizing some of the suggestions emerging from workshop discussions and the accompanying review with respect to energy democracy. This leads us to set out three main areas for remaking energy democracy in practice, based on the need for: (i) reflexive and experimental energy participation; (ii) responsible energy democratization; and (iii) socially responsive energy governance.

\section{Reflexive and Experimental Energy Participation}

Relational perspectives focus attention onto the ways in which practices of energy democracy construct, frame, cause exclusions and effects in relation to the models (formats), subjects (participants), and objects (issues) of energy participation (cf. Chilvers and Longhurst, 2016). A major implication of this is that these dynamics should be deliberately and reflexively attended to in the performance of energy democracy in practice. Reflexivity in this regard means critically attending to closures (framing effects) or deliberately opening up the objects, subjects and models of energy democratic practices in terms of their construction, performance, publicity and systemic relations. In other words, relational and co-productionist perspectives call on those actors or institutions intervening in practices of energy democracy and participation to be openly and reflexively aware of their own assumptions and co-productive effects, as well as those of others.
There are several relational approaches that have been developed to more actively intervene in or create participation processes, though only a subset of these have thus far been attempted with regards to energy-related issues. These approaches draw upon relational arguments to inform new ways of doing engagement, which attempt to reconfigure participatory practices in ways that are reflexive, experimental, material, anticipatory, and/or speculative. These approaches also rely on different notions of effectiveness and focus their efforts on different elements. For example, the robustness of processes and outcomes is no longer judged only on the basis of statistical significance, the achievement of consensus, or the authenticity of the public voices represented, but rather on virtues such as reflexivity, the anticipation of unintended consequences, humility, and the reflection of uncertainties in participatory process reporting.

One strategy for developing reflexive practices of energy democracy is to take existing participatory methods and tools and imbue them with reflexive intent. For example, as Brian Wynne (2006a) has shown, even established social science methods like focus groups can attend to reflexivity in this way, through researchers being aware of how the research intervention shapes publics (such as upland sheep farmers facing radioactive fallout from the Chernobyl nuclear disaster), thus openly revealing emergent publics and inherent ambiguities in public concerns (see also Macnaghten et al., 2015). Examples also exist of attempts to make deliberative forms of energy democracy more reflexive about the ways in which they frame the objects (issues) of public deliberation. A good example is Deliberative Mapping (DM)-a hybrid multi-criteria options appraisal tool that seeks to engage citizens and specialists together in a symmetrical manner. By enabling participants to define the issue at hand, options for appraisal, and the criteria with which to perform the appraisal, DM has been used to open up the framings of both the objects and subjects of participation on radioactive waste management (Chilvers and Burgess, 2008) and geoengineering of climate change (Bellamy et al., 2016).

Another strategy is to take a more explicitly experimental approach to the formation of energy democratic practices. Processes of "collective experimentation" (Felt and Wynne, 2007) have been developed by advocates of relational STS understandings of participation, attempting not only to experiment with ideas and different understandings of the issue in question, but also with different forms of organizationintroducing reflexivity around the models of participation adopted and the kinds of publics enrolled in these processes. For example, work by Callon et al. (2009) has sought to bring about heterogeneous participatory collectives of humans and nonhumans-which they refer to as "hybrid forums"-in various contexts, including the cases of nuclear waste management. A similar approach has been put into practice by Matthias Gross in the context of ecological restoration projects (e.g., Gross, 2010), evoking an attitude of constant experimentation, monitoring, and shifting socio-material organization. Speculative design is another interventionist method which has been developed out of relational STS arguments, in particular object-oriented approaches. It is a model of designerly practice that attempts to 
create new objects with close attention paid to the construction of intended users and the emergent modes of social organization they will be associated with. There are multiple examples of speculative design related to the energy field, such as in relation to so-called smart technologies for the home and environmental monitoring technologies (e.g., Gabrys, 2014; Wilkie et al., 2015; Michael, 2016).

A further set of possibilities exist around being reflexive about the actual models or "atmospheres of democracy" (Latour and Weibel, 2005) that are brought into being in energy-related participation. Where models in typical deliberative workshops have been one-off events that assume a deliberative democratic constitution, recent work by Bellamy et al. (2017) has experimented with deliberately constructing more centralized, competitive, and consensual modes of deliberation and exploring how these different "atmospheres" shape public views on the governance of climate geoengineering technologies. Work that actively experiments with the formats of energy participation is also emerging in practice theory. This includes attempts to reconfigure everyday practices-thatuse-energy through deliberately changing aspects of practice in an experimental fashion, and then monitoring subsequent changes. For example Higginson et al. (2014) have experimented with changing the timings of particular energy-using practices, while Jack (2013) asked practitioners to avoid washing their denim jeans for a 3-month period and then tracked the new understandings and competences they developed around laundry and clothing-related practices.

Even where constructions and framing effects have not been considered in "real time" during the performance of energy democratic practices, they can still be attended to in how instances of public engagement with energy are publicized. Even after the "event" of participation those intervening in energy democratic practices should ask: is it possible to represent publics in ways that pay due account of the inherent uncertainties, indeterminacies, contingencies and framing effects of their production? In this sense, social scientists and public engagement practitioners should do more to open up and communicate uncertainties about energy participation and publics-pertaining to the way they have been constructed, possible alternatives, and exclusions. Uncertainty is not only a concern for energy modelers, but for those modeling energy publics too. The evaluation frameworks which are used for judging the effectiveness of behavior change programmes or deliberative consultations, for example, also need to open up these uncertainties. They should not only be concerned with inclusion and linear impacts on decision processes, but need to also consider significant exclusions and wider effects.

Finally-with reference to the recommendations in the above sections to move beyond conceiving of energy democracy in terms of discrete cases and to move toward mapping approaches-there is a need to develop new reflexive practices and methods that map diversities of already existing collectives through which publics engage with energy and their interrelations within wider systems. In this regard a range of promising mapping methods are emerging in the energy field and beyond, such as issue mapping (Marres, 2015), controversy mapping (Latour,
2005; Venturini, 2010), comparative cases analyses (Chilvers and Longhurst, 2016), systematic reviews (Pallett et al., 2017), and network analysis (Higginson et al., 2015). Such maps produce public documents (evidence for all system actors, not only for policy-makers) that reveal hidden diversities of participation and thus offer a means of enhancing public accountability and transparency of decision institutions. The act of mapping diversities can reveal and make public otherwise denied or marginalized perspectives, concerns and actions, and serve as a basis for harnessing citizen innovations and energies.

\section{Responsible Energy Democracy}

Mainstream approaches to practicing public engagement with energy tend to emphasize the positive aspects of participation. For example, evaluation frameworks focus on the energy savings or carbon reductions of behavior change initiatives (Dolan et al., 2012), or on the inclusivity, representativeness, and decision impact of deliberative processes (Renn et al., 1995). In contrast, relational and constructivist approaches to democratizing energy show that practices of public engagement can have negative as well as positive effects and outcomes, or bring about unintended consequences in the longer term. Grassroots and community based energy initiatives, which represent great opportunities to democratize and socially shape energy transitions, might actually be quite exclusive and exclude, marginalize and disempower actors and perspectives in specific localities (Smith et al., 2016). Behavior change initiatives and the provision of energy feedback to consumers might lead to some reductions in energy use while locking consumers into unsustainable social relationships and leading to rebound effects (cf. Hargreaves, 2018).

So, a second practical move urged by relational understandings of energy democracy is to actively anticipate and take responsibility for possible downsides, purposes and social/ethical implications before and during-not just after-the event of participation and democratic engagement. In this sense forms of energy democracy need to become what Chilvers and Kearnes (2016c) term "responsible democratic innovations" which requires anticipation, "opening up and accounting for the inherent uncertainties, framing effects, politics, power relations, social assumptions, and unintended consequences of emergent technologies of participation" (p. 276). In many respects this mirrors and can make use of tools developed by work in STS that seeks to responsibly develop emerging science and technologies through reflexive consideration and anticipation of their underlying purposes, consequences, social assumptions, and ethical dimensions in processes of technology assessment (Rip, 1996), anticipatory governance (Guston, 2014), and responsible innovation (Owen et al., 2013).

Technology assessment and foresight processes could be used to anticipate the how particular innovations in energy democracy might co-evolve with science and society in the future (for an example of this applied to citizens panels see Voß, 2016). There is also scope for social scientists to work interactively with engagement practitioners in the "social laboratories" of energy democracy-whether they be community organizers of grassroots innovations, activists, facilitators of deliberative processes, designers of digital methods, and so on-to get them 
to reflect, anticipate and respond to the possible social and ethical implications and effects of their democratic innovations in "real time" (cf. Fisher et al., 2015). When the move is made to take a more responsible and careful approach to energy democracy the possibilities multiply, including the potential to reconfigure existing processes of learning and evaluation and imbue them with more reflexive and responsible intent (e.g., Mohr et al., 2013).

Such thinking brings into focus long-standing debates about appropriate and effective forms of academic critique and intervention. Workshop discussions (Chilvers and Pallett, 2015) considered, for example, the extent to which researchers should couch interventions and commentaries in the language and framing of currently dominant regimes, or whether the stance of academic theories such as Actor-Network Theory should be considered apolitical or deeply normative. Workshop discussion also spoke to the need for (social) scientists to take up a diversity of roles when interacting with and intervening in practices of energy democracy including: the formation of distant or more radical critiques (Shove, 2010), the provision of more abstract and systemic conceptual frameworks (such as those outlined in the section on Relational Concepts and Theories), providing expert advice in more policy relevant ways (Owens, 2015), to adopt more activist positions and engaging with social movements (Taylor, 2014), through to the development and mediation of new forms of energy democracy (such as the examples provided in the section on Reflexive and Experimental Energy Participation above). However, some of the workshop presentations and plenary discussions reported on in Chilvers and Pallett (2015) also hinted at further dimensions to this well-worn debate, in particular highlighting the importance of being aware of long term driving forces, systemic stabilities, and political situations when forming academic and practitioner interventions and deciding when is an appropriate time to act. This also hints at a need for more constitutional or system-wide understandings of the energy system in academic work on energy publics, including a broader historical and geographical span of relevant processes and structures. A relational approach resists seeing these dimensions merely as "constraints" which practitioners should work within, to emphasize how extant powers and orders that shape energy democracies should also be openly exposed, resisted, reconfigured, and transformed.

\section{Socially Responsive Energy Governance}

Finally, relational perspectives on energy democracy urge consideration of how institutions, systems of governance, and various system actors (including publics themselves) might better acknowledge, account for and be responsive to diverse and emergent energy publics. A recognition of the diversity of emerging energy publics thus raises broader questions for academics and wider society, around what it means to govern in the "public interest" or "public good," under such complex and uncertain conditions. This calls for greater responsiveness on the part of institutions and system actors to the diversities, emergence, and productivities of the practices through which publics engage with energy transitions.
Relational and co-productionist perspectives fundamentally challenge mainstream understandings of energy democracy as a "problem of extension" where the burden is placed on publics to engage with, change, get in line, or respond to trajectories and definitions of "the energy transition" defined by others (most often institutional authorities, whether that be science, the state or industry, but also increasingly groups in civil society). Relational accounts recast the challenge as a "problem of relevance" where the problem is one of incumbent institutions (and to some extent publics themselves) accounting for the relevance of diverse and already existing forms of participation and public engagement that make up the energy systems and their futures (cf. Wynne, 2007; Marres, 2012). In short, the move is from seeing participation as simply about eliciting public views on energy systems in invited events, to seeing it as a challenge of mapping the diversities, relations, and productions of already existing forms of participation across energy systems. This shift of emphasis, to recognize distributed agencies in the form of collective participatory practices, potentially provides the basis for breakthroughs in how to tackle issues of equity, inclusion, institutional responsiveness, and social change with regards to participation in whole energy systems.

These insights effectively turn participation and energy democracies around, prompting new ways of governing energy transitions. They mark a shift away from an exclusive drive to elicit and aggregate public views in forming a vision of 'the transition' which is then centrally managed, toward more distributed and responsive styles of governing energy transitions. Given that societal engagements in the energy system are continually emerging - imagining, knowing and doing in different ways - the challenge is to develop systems of governance that are more responsive and accountable to these diverse and continually emerging forms of 'public interest', value and action. This demands new forms of institutional listening (cf. Dobson, 2014) to diverse forms of energy public relevance, and new ways of seeing emergent energy public doings, that might otherwise be excluded or denied. This more open, responsive and outward looking approach to governing energy transitions should attend to the emergence and overflows of energy participation and promote institutional learning and responsiveness to new framings of energy issues, publics, and forms of energy democracy.

\section{CONCLUSION}

In this paper, we have argued that "energy democracy" is not a simple or neutral object, but rather something which needs careful unpacking and reflexive examination to be useful and productive. Acknowledging the "essentially contested" nature of democracy (cf. Gallie, 1955) - and therefore participation and publics-opens up a more reflexive and critical approach to this emerging object of energy participation. The approach we advocate recognizes and explores the multiplicity and diversity of energy publics and participation, and therefore visions of what energy democracy might look like, rather than adopting 
a singular model or vision of energy democracy, such as community energy or deliberative engagement.

The diversity of energy publics and participation, and of academic work around these objects, which we have demonstrated in this paper, shows the need for more symmetrical, co-productive, and comparative analyses of the emergence of energy publics. This necessitates developing conceptual frameworks which enable the analysis of contrasting energy publics and forms of participation, and allow researchers and practitioners to compare across diverse cases and cultures. We argue that these frameworks should also be co-productive so that they acknowledge the relational emergence of energy publics and participation, rather than adopting the fixed realist perspectives we criticized in the section on Energy Democracies and Publics in the Making.

Academic work on energy democracy also needs to openly acknowledge the inevitable partiality of the accounts produced, shaped as they are by theoretical and methodological leanings, and the limitations of time and other logistical elements. We need to find better ways of writing about this and highlighting it when we are called upon to give advice and guidance. This also requires us to recognize the performativity of our accounts, in the way that they shape people's own understandings of what they are engaged in, as well as governing or other official narratives about energy participation and democracy. In the energy field, perhaps more than any other, we need to be aware that our theories and concepts are already out there "in the wild" of the

\section{REFERENCES}

Abrahamse, W., Steg, L., Vlek, C., and Rothengatter, T. (2005). A review of intervention studies aimed at household energy conservation. J. Environ. Psychol. 25, 273-291. doi: 10.1016/j.jenvp.2005.08.002

Araújo, K. (2014). The emerging field of energy transitions: progress, challenges, and opportunities. Energy Res. Soc. Sci. 1, 112-121. doi: $10.1016 /$ j.erss.2014.03.002

Asdal, K., and Marres, N. (2014). Performing environmental change: the politics of social science methods. Environ. Plann. A 46, 2055-2064. doi: 10.1068/a140292e

Barnett, J., Burningham, K., Walker, G., and Cass, N. (2010). Imagined publics and engagement around renewable energy technologies in the UK. Public Underst. Sci. 21, 36-50. doi: 10.1177/0963662510365663

Barry, A. (2012). Political situations: knowledge controversies in transnational governance. Critic. Policy Stud. 6, 324-336. doi: 10.1080/19460171.2012. 699234

Barry, A. (2013). Material Politics: Disputes Along the Pipeline. Chichester: Wiley.

Bauer, A., and Pregernig, M. (2013). Whose look into the future? Participation in technology assessment and foresight. Crit. Policy Stud. 7, 18-36. doi: 10.1080/19460171.2012.745992

Becker, S., and Naumann, M. (2017). Energy democracy: mapping the debate on energy alternatives. Geogr. Compass 11:e12321. doi: 10.1111/gec3.12321

Bellamy, R., Chilvers, J., and Vaughan, N. E. (2016). Deliberative mapping of options for tackling climate change: citizens and specialists 'open up' appraisal of geoengineering. Public Underst. Sci. 25, 269-286. doi: $10.1177 / 0963662514548628$

Bellamy, R., Lezaun, J., and Palmer, J. (2017). Public perceptions of geoengineering research governance: an experimental deliberative approach. Glob. Environ. Change 45, 194-202. doi: 10.1016/j.gloenvcha.2017. 06.004 processes we are studying (cf. Callon et al., 2009), and therefore not entirely under our control or according with our specific definitions.

These conclusions have far-reaching implications for academic theorization, empirical work, and policy-practice, which we have tried to explore and propose in this paper. We hope in particular, that the key points summarized at the end of each sub-section in the section on A Relational Agenda for Energy Democracy Research and Practice will be of use to academics and practitioners wanting to weave these insights into their theories, methods, and practice, along with the experimental and reflexive disposition which we advocate.

\section{AUTHOR CONTRIBUTIONS}

Both authors made equal contributions to writing this article. The expert workshop which the article partly draws on was designed, organized and facilitated by JC and HP. JC led the project in which this research was undertaken.

\section{ACKNOWLEDGMENTS}

The research presented in this paper was funded by the UK Engineering and Physical Sciences Research Council (EPSRC) [Grant number EP/K005316/1] and also benefited from support from the UK Research Councils as part of the UK Energy Research Centre Phase 3 research programme [EPSRC award EP/L024756/1].

Bennett, J. (2009). Vibrant Matter: A Political Ecology of Things. London: Duke University Press.

Blake, J. (1999). Overcoming the 'value-action gap' in environmental policy: tensions between national policy and local experience. Local Environ. 4, 257-278. doi: 10.1080/13549839908725599

Bowness, E., and Hudson, M. (2014). Sand in the cogs? Power and public participation in the Alberta tar sands. Environ. Polit. 23, 59-76. doi: 10.1080/09644016.2013.821825

Bristow, G., Cowell, R., and Munday, M. (2012). Windfalls for whom? The evolving notion of 'community' in community benefit provisions from wind farms. Geoforum 43, 1108-1120. doi: 10.1016/j.geoforum.2012.06.015

Burgess, J., and Chilvers, J. (2006). Upping the ante: a conceptual framework for designing and evaluating participatory technology assessments. Sci. Public Policy 33, 713-728. doi: 10.3152/147154306781778551

Burke, M. J., and Stephens, J. C. (2017). Energy democracy: goals and policy instruments for sociotechnical transitions. Energy Res. Soc. Sci. 33, 35-48. doi: 10.1016/j.erss.2017.09.024

Butler, C., Parkhill, K. A., Shirani, F., Henwood, K., and Pidgeon, N. (2014). Examining the dynamics of energy demand through a biographical lens. Nat. Cult. 9, 164-182. doi: 10.3167/nc.2014.090204

Callon, M., Lascoumes, P., and Barthe, Y. (2009). Acting in an Uncertain World: An Essay on Technical Democracy. Cambridge, MA: MIT Press.

Carlson, J. D. (2014). Unruly Energies: Provocations of Renewable Energy Development in a Northern German Village. Austin: The University of Texas at Austin.

Chilvers, J. (2008). Environmental risk, uncertainty, and participation: mapping an emergent epistemic community. Environ. Plann. A 40, 2990-3008. doi: $10.1068 /$ a39279

Chilvers, J., and Burgess, J. (2008). Power relations: the politics of risk and procedure in nuclear waste governance. Environ. Plann. A 40, 1881-1900. doi: $10.1068 / \mathrm{a} 40334$ 
Chilvers, J., and Kearnes, M. (eds.). (2016a). Remaking Participation: Science, Environment and Emergent Publics. (Abingdon; Oxon: Routledge).

Chilvers, J., and Kearnes, M. (eds.). (2016b). "Participation in the making: rethinking public engagement in co-productionist terms," in Remaking Participation: Science, Environment and Emergent Publics (Abingdon: Routledge), 31-63.

Chilvers, J., and Kearnes, M. (eds.). (2016c). "Remaking participation: towards reflexive engagement," in Remaking Participation: Science, Environment and Emergent Publics (Abingdon: Routledge), 261-288.

Chilvers, J., and Longhurst, N. (2012). Paritcipation, Politics and Actor Dynamics in Low Carbon Energy Transitions-Report of a Transition Pathways Project workshop. Norwich: 3S Research Group.

Chilvers, J., and Longhurst, N. (2016). Participation in transition(s): reconceiving public engagements in energy transitions as coproduced, emergent and diverse. J. Environ. Policy Plann. 18, 585-607. doi: 10.1080/1523908X.2015.1110483

Chilvers, J., and Pallett, H. (2015). Making Energy Publics: Workshop Report. Norwich: Science, Society and Sustainability Research Group, UEA.

Cotton, M., and Devine-Wright, P. (2012). Making electricity networks "visible": industry actor representations of "publics" and public engagement in infrastructure planning. Public Underst. Sci. 21, 17-35. doi: $10.1177 / 0963662510362658$

Cowell, R. (2010). Wind power, landscape and strategic, spatial planning-The construction of 'acceptable locations' in Wales. Land Use Policy 27, 222-232. doi: 10.1016/j.landusepol.2009.01.006

Cowell, R., Bristow, G., and Munday, M. (2011). Acceptance, acceptability and environmental justice: the role of community benefits in wind energy development. J. Environ. Plann. Manag. 54, 539-557. doi: 10.1080/09640568.2010.521047

Cozen, B., Endres, D., Peterson, T. R., Horton, C., and Barnett, J. T. (2018). Energy communication: theory and praxis towards a sustainable energy future. Environ. Commun. 12, 289-294. doi: 10.1080/17524032.2017. 1398176

Devine-Wright, P. (2007). "Energy citizenship: psychological aspects of evolution in sustainable energy technologies," in Governing Technology for Sustainability, eds J. Murphy (London: Earthscan), 63-86.

Dobson, A. (2014). Listening for Democracy: Recognition, Representation, Reconciliation. Oxford: Oxford University Press.

Dolan, P., Hallsworth, M., Halpern, D., King, D., Metcalfe, R., and Vlaev, I. (2012). Influencing behaviour: the mindspace way. J. Econ. Psychol. 33, 264-277. doi: 10.1016/j.joep.2011.10.009

Eaton, W. M., Gasteyer, S. P., and Busch, L. (2014). Bioenergy futures: framing sociotechnical imaginaries in local places. Rural Sociol. 79, 227-256. doi: $10.1111 /$ ruso. 12027

ECDC (2017). Energy \& Co-designing Communities Project. Available online at: http://archive.is/Zk5ru (Accessed July 11, 2017).

Einsiedel, E. F., Boyd, A. D., Medlock, J., and Ashworth, P. (2013). Assessing socio-technical mindsets: public deliberations on carbon capture and storage in the context of energy sources and climate change. Energy Policy 53, 149-158. doi: 10.1016/j.enpol.2012.10.042

Elam, M., Reynolds, L., Soneryd, L., Sundqvist, G., and Szerszynski, B. (2007). Mediators of Issues and Mediators of Process - A Theoretical Framework. (Göteborg: Göteborg University).

Endres, D. E., Cozen, B., Trey Barnett, J., O’byrne, M., and Rai Peterson, T. (2016). Communicating energy in a climate (of) crisis. Ann. Int. Commun. Assoc 40, 419-447. doi: 10.1080/23808985.2015.11735267

Fairchild, D., and Weinrub, A. (2017). Energy Democracy: Advancing Equity in Clean Energy Solutions. Washington, DC: Island Press.

Felt, U., and Wynne, B. (2007). Taking European Knowledge Society Seriously. Brussels: European Commission.

Fisher, E., O'rourke, M., Evans, R., Kennedy, E. B., Gorman, M. E., and Seager, T. P. (2015). Mapping the integrative field: taking stock of socio-technical collaborations. J. Respons. Innov. 2, 39-61. doi: 10.1080/23299460.2014.1001671

Gabrys, J. (2014). A cosmopolitics of energy: diverging materialities and hesitating practices. Environ. Plann. A 46, 2095-2109. doi: 10.1068/a468

Gallie, W. B. (1955). Essentially contested concepts. Proc. Aristot. Soc. 56, 167-198.
Goulden, M., Bedwell, B., Rennick-Egglestone, S., Rodden, T., and Spence, A. (2014). Smart grids, smart users? The role of the user in demand side management. Energy Res. Soc. Sci. 2, 21-29. doi: 10.1016/j.erss.2014.04.008

Gross, M. (2010). the public proceduralization of contingency: bruno latour and the formation of collective experiments. Soc. Epistemol. 24, 63-74. doi: 10.1080/02691721003632826

Grove-White, R., Kearnes, M., Macnaghten, P., and Wynne, B. (2006). Nuclear futures: assessing public attitudes to new nuclear power. Polit. Q. 77, 238-246. doi: 10.1111/j.1467-923X.2006.00766.x

Guston, D. H. (2014). Understanding 'anticipatory governance'. Soc. Stud. Sci. 44, 218-242. doi: 10.1177/0306312713508669

Hammond, G. P., and Pearson, P. J. (2013). Challenges of the transition to a low carbon, more electric future: from here to 2050. Energy Policy 52, 1-9. doi: 10.1016/j.enpol.2012.10.052

Hargreaves, T. (2013). "Smart meters and the governance of energy use in the household," in Governing The Climate: New Approaches to Rationality, Power and Politics, eds J. Stripple and H. Bulkeley (Cambridge, MA: Cambridge University Press), 127-143.

Hargreaves, T. (2018). Beyond energy feedback. Build. Res. Inform. 46, 332-342. doi: 10.1080/09613218.2017.1356140

Hargreaves, T., Nye, M., and Burgess, J. (2013). Keeping energy visible? Exploring how householders interact with feedback from smart energy monitors in the longer term. Energy policy 52, 126-134. doi: 10.1016/j.enpol.2012. 03.027

Hendriks, C. M. (2009). Policy design without democracy? Making democratic sense of transition management. Policy Sci. 42, 341-368. doi: 10.1007/s11077-009-9095-1

Hess, D. J. (2018). Energy democracy and social movements: a multi-coalition perspective on the politics of sustainability transitions. Energy Res. Soc. Sci. 40, 177-189. doi: 10.1016/j.erss.2018.01.003

Higginson, S., Mckenna, E., Hargreaves, T., Chilvers, J., and Thomson, M. (2015). Diagramming social practice theory: an interdisciplinary experiment exploring practices as networks. Indoor Built Environ. 24, 950-969. doi: $10.1177 / 1420326 \mathrm{X} 15603439$

Higginson, S., Thomson, M., and Bhamra, T. (2014). "For the times they are achangin": the impact of shifting energy-use practices in time and space. Local Environ. 19, 520-538. doi: 10.1080/13549839.2013.802459

Hui, A., Schatzki, T., and Shove, E. (2016). The Nexus of Practices: Connections, Constellations, Practitioners. Abingdon: Routledge.

Irwin, A. (2001). Constructing the scientific citizen: science and democracy in the biosciences. Public Underst. Sci. 10, 1-18. doi: 10.1088/0963-6625/10/1/301

Irwin, A. (2006). The politics of talk: coming to terms with the 'new' scientific governance. Soc. Stud. Sci. 36, 299-320. doi: 10.1177/03063127060 53350

Irwin, A., and Michael, M. (2003). Science, Social Theory and Public Knowledge. Maidenhead: Open University Press.

Jack, T. (2013). Laundry routine and resource consumption in Australia. Int. J. Consum. Stud. 37, 666-674. doi: 10.1111/ijcs.12048

Jasanoff, S. ed (2004). States of Knowledge: The Co-production of Science and Social Order. Abingdon: Routledge.

Jasanoff, S. (2011). Constitutional moments in governing science and technology. Sci. Eng. Ethics 17, 621-638. doi: 10.1007/s11948-011-9302-2

Jasanoff, S. (2017). Virtual, visible, and actionable: data assemblages and the sightlines of justice. Big Data Soc. 4, 1-15. doi: 10.1177/2053951717724477

Jasanoff, S., and Kim, S.-H. (2009). Containing the atom: sociotechnical imaginaries and nuclear power in the United States and South Korea. Minerva 47, 119-146. doi: 10.1007/s11024-009-9124-4

Jasanoff, S., and Kim, S.-H. (2013). Sociotechnical imaginaries and National Energy Policies. Sci. Cult. 22, 189-196. doi: 10.1080/09505431.2013.786990

Jaspal, R., and Nerlich, B. (2014). Fracking in the UK Press: threat dynamics in an unfolding debate. Public Underst. Sci. 23, 348-363. doi: $10.1177 / 0963662513498835$

Jones, R., Pykett, J., and Whitehead, M. (2013). Changing Behaviours: on the Rise of the Psychological State. Cheltenham: Edward Elgar.

Kim, H. (2014). Reconstructing the public in old and new governance: a Korean case of nuclear energy policy. Public Underst. Sci. 23, 268-282. doi: $10.1177 / 0963662514524087$ 
Krauss, W. (2010). The 'dingpolitik' of wind energy in northern German landscapes: an Ethnographic Case Study. Landscape Res. 35, 195-208. doi: $10.1080 / 01426390903557972$

Kunze, C., and Becker, S. (2014). Energy Democracy in Europe: A Survey and Outlook. Brussels: Rosa Luxenburg Stiftung.

Laird, F. N. (2013). Against transitions? Uncovering conflicts in changing energy systems. Sci. Cult. 22, 149-156. doi: 10.1080/09505431.2013.786992

Latour, B. (2005). Reassembling the Social: An Introduction to Actor-NetworkTheory. Oxford: Oxford University Press.

Latour, B., and Weibel, P. (2005). Making Things Public: Atmospheres of Democracy. Cambridge, MA: MIT Press.

Laurent, B. (2011). Technologies of democracy: experiments and demonstrations. Sci. Eng. Ethics 17, 649-666. doi: 10.1007/s11948-011-9303-1

Lee, M., Armeni, C., Cendra, J. D., Chaytor, S., Lock, S., Maslin, M., et al. (2012). Public participation and climate change infrastructure. J. Environ. Law 25, 33-62. doi: 10.1093/jel/eqs027

Lezaun, J., and Soneryd, L. (2007). Consulting citizens: technologies of elicitation and the mobility of publics. Public Underst. Sci. 16, 279-297. doi: $10.1177 / 0963662507079371$

Lock, S. J., Smallman, M., Lee, M., and Rydin, Y. (2014). "Nuclear energy sounded wonderful 40 years ago": UK citizen views on CCS. Energy Policy 66, 428-435. doi: 10.1016/j.enpol.2013.11.024

Macnaghten, P., and Chilvers, J. (2014). The future of science governance: publics, policies, practices. Environ. Plan. C Govern. Policy 32, 530-548. doi: $10.1068 / \mathrm{c} 1245 \mathrm{j}$

Macnaghten, P., Davies, S. R., and Kearnes, M. (2015). Understanding public responses to emerging technologies: a narrative approach. J. Environ. Policy Plan. 1-19. doi: 10.1080/1523908X.2015.1053110

Mahony, N., Newman, J., and Barnett, C. (eds.) (2010). Rethinking the Public: Innovations in Research, Theory and Politics. Bristol: Policy Press.

Marres, N. (2007). The issues deserve more credit: pragmatist contributions to the study of public involvement in controversy. Soc. Stud. Sci. 37, 759-780. doi: $10.1177 / 0306312706077367$

Marres, N. (2011). The costs of public involvement: everyday devices of carbon accounting and the materialization of participation. Econ. Soc. 40, 510-533. doi: 10.1080/03085147.2011. 602294

Marres, N. (2012). Material Participation: Technology, the Environment and Everyday Publics. Basingstoke: Palgrave Macmillan.

Marres, N. (2015). Why map issues? On controversy analysis as a digital method. Sci. Technol. Hum. Valu. 40, 655-686. doi: 10.1177/0162243915574602

Marres, N. (2017). Digital Sociology: The Reinvention of Social Research. Cambridge: Polity Press.

Marres, N., and Lezaun, J. (2011). Materials and devices of the public: an introduction. Econ. Soc. 40, 489-509. doi: 10.1080/03085147.2011.602293

Michael, M. (2016). "Engaging the mundane: complexity and speculation in everyday technoscience," in Remaking Participation: Science, Environment and Emergent Publics, eds J. Chilvers and M. Michael (Abingdon; Oxon: Routledge), $81-98$.

Miller, C. A., Iles, A., and Jones, C. F. (2013). The social dimensions of energy transitions. Sci. Cult. 22, 135-148. doi: 10.1080/09505431.2013.786989

Miller, C. A., Richter, J., and O'leary, J. (2015). Socio-energy systems design: a policy framework for energy transitions. Energy Res. Soc. Sci. 6, 29-40.

Moezzi, M., Janda, K. B., and Rotmann, S. (2017). Using stories, narratives, and storytelling in energy and climate change research. Energy Res. Soc. Sci. 31, 1-10. doi: 10.1016/j.erss.2017.06.034

Mohr, A., Raman, S., and Gibbs, B. (2013). Which publics? When? Exploring the Policy Potential of Involving Different Publics in Dialogue Around Science and Technology. London: Sciencewise.

Morris, C., and Jungjohann, A. (2016). Energy Democracy: Germany's Energiewende to Renewables. London: Springer.

North, P. (2011). The politics of climate activism in the UK: a social movement analysis. Environ. Plan. A 43, 1581-1598. doi: 10.1068/a43534

Nowotny, H., Scott, P., and Gibbons, M. (2001). Re-Thinking Science: Knowledge and the Public in an Age of Uncertainty. Cambridge: Polity.

Owen, R., Bessant, J., and Heitz, M. (eds.) (2013). Responsible Innovation: Managing the Responsible Emergence of Science and Innovation in Society. Chichester: Wiley.
Owen, D., and Smith, G. (2015). Survey article: deliberation, democracy, and the systemic turn. J. Polit. Philos. 23, 213-234. doi: 10.1111/jopp.12054

Owens, S. (2015). Knowledge, Policy, and Expertise: The UK Royal Commission on Environmental Pollution 1970-2011. Oxford: OUP.

Owens, S., and Driffill, L. (2008). How to change attitudes and behaviours in the context of energy. Energy Policy 36, 4412-4418. doi: 10.1016/j.enpol.2008.09.031

Pacheco, D. F., York, J. G., and Hargrave, T. J. (2014). The coevolution of industries, social movements, and institutions: wind power in the United States. Organ. Sci. 25, 1609-1632. doi: 10.1287/orsc.2014.0918

Pallett, H., and Chilvers, J. (2013). A decade of learning about publics, participation, and climate change: institutionalising reflexivity? Environ. Plan. A 45, 1162-1183. doi: 10.1068/a45252

Pallett, H., Chilvers, J., and Hargreaves, T. (2017). Mapping Energy Participation: a systematic review of diverse practices of public participation in energy transitions 2010-1015. London: UK Energy Research Centre.

Parkinson, J., and Mansbridge, J. eds (2012). Deliberative Systems: Deliberative Democracy at the Large Scale. Cambridge: Cambridge University Press.

Pidgeon, N., Demski, C., Butler, C., Parkhill, K., and Spence, A. (2014). Creating a national citizen engagement process for energy policy. Proc. Natl. Acad. Sci. U.S.A. 111(Suppl.), 13606-13613. doi: 10.1073/pnas.1317512111

Raven, P. G. (2017). Telling tomorrows: science fiction as an energy futures research tool. Energy Res. Soc. Sci. 31, 164-169. doi: 10.1016/j.erss.2017.05.034

Renn, O., Webler, T., and Wiedemann, P. (1995). Fairness and Competence in Citizen Participation: Evaluating Models for Environmental Discourse. Dordrecht: Kluwer.

Rip, A. (1996). Managing Technology in Society. London: Pinter.

Rogers, R. (2013). Digital Methods. Cambridge, MA: MIT Press.

Saunders, C., and Price, S. (2009). One person's eu-topia, another's hell: climate Camp as a heterotopia. Environ. Polit. 18, 117-122. doi: $10.1080 / 09644010802624850$

Seyfang, G., and Haxeltine, A. (2012). Growing grassroots innovations: exploring the role of community-based initiatives in governing sustainable energy transitions. Environ. Plan. C Govern. Policy 30, 381-400. doi: 10.1068/ c10222

Seyfang, G., Park, J. J., and Smith, A. (2013). A thousand flowers blooming? An examination of community energy in the UK. Energy Policy 61, 977-989. doi: 10.1016/j.enpol.2013.06.030

Shirani, F., Butler, C., Henwood, K., Parkhill, K., and Pidgeon, N. (2015). 'I'm not a tree hugger, I'm just like you': changing perceptions of sustainable lifestyles. Environ. Polit. 24, 57-74. doi: 10.1080/09644016.2014.959247

Shove, E. (1998). Gaps, barriers and conceptual chasms: theories of technology transfer and energy in buildings. Energy Policy 26, 1105-1112. doi: 10.1016/S0301-4215(98)00065-2

Shove, E. (2010). Beyond the ABC: climate change policy and theories of social change. Environ. Plan. A 42, 1273-1285. doi: 10.1068/a42282

Shove, E., Pantzar, M., and Watson, M. (2012). The Dynamics of Social Practice: Everyday Life and How It Changes. London: Sage.

Smith, A., Hargreaves, T., Hielscher, S., Martiskainen, M., and Seyfang, G. (2016). Making the most of community energies: three perspectives on grassroots innovation. Environ. Plan. A 48, 407-432. doi: 10.1177/0308518X155 97908

Smith, J., Butler, R., Day, R. J., Goodbody, A. H., Llewellyn, D. H., Rohse, M. H., et al. (2017). Gathering around stories: interdisciplinary experiments in support of energy system transitions. Energy Res. Soc. Sci. 31, 284-294. doi: 10.1016/j.erss.2017.06.026

Smith, J. M., and Tidwell, A. S. (2016). The everyday lives of energy transitions: contested sociotechnical imaginaries in the American West. Soc. Stud. Sci. 46, 327-350. doi: 10.1177/0306312716644534

Soneryd, L. (2016). "Technologies of participation and the making of technologized futures," in Remaking Participation: Science, Environment and Emergent Publics, eds J. Chilvers and M. Kearnes (Abingdon; Oxon: Routledge), 144-161.

Sovacool, B. K. (2014). What are we doing here? Analyzing fifteen years of energy scholarship and proposing a social science research agenda. Energy Res. Soc. Sci. 1, 1-29. doi: 10.1016/j.erss.2014.02.003

Stagl, S. (2006). Multicriteria evaluation and public participation: the case of UK energy policy. Land Policy 23, 53-62. doi: 10.1016/j.landusepol.2004.08.007 
Stirling, A. (2008). "Opening up" and "Closing down" - power, participation, and pluralism in the social appraisal of technology. Sci. Technol. Hum. Valu. 33, 262-294. doi: 10.1177/0162243907311265

Stirling, A. (2014). Transforming power: social science and the politics of energy choices. Energy Res. Soc. Sci. 1, 83-95. doi: 10.1016/j.erss.2014.02.001

Strengers, Y. (2013). Smart Energy Technologies in Everyday Life: Smart Utopia? London: Palgrave.

Szulecki, K. (2018). Conceptualizing energy democracy. Environ. Polit. 27, 21-41. doi: 10.1080/09644016.2017.1387294

Taylor, M. (2014). 'Being useful'after the Ivory Tower: combining research and activism with the Brixton Pound. Area 46, 305-312. doi: 10.1111/area.12117

TNS BMRB, (2014). Public Engagement with Shale Gas and Oil. London: TNS BMRB.

Van Veelen, B. (2018). Negotiating energy democracy in practice: governance processes in community energy projects. Environ. Polit. 1-22. doi: 10.1080/09644016.2018.1427824

Venturini, T. (2010). Diving in magma: how to explore controversies with actor-network theory. Public Underst. Sci. 19, 258-273. doi: 10.1177/0963662509102694

Voß, J.-P. (2016). "Reflexively engaging with technologies of participation: constructive assessment for public participation methods," in Remaking Participation: Science, Environment and Emergent Publics, eds J. Chilvers and M. Kearnes (Abingdon, Oxon: Routledge), 238-260.

Walker, G., and Cass, N. (2007). Carbon reduction, 'the public' and renewable energy: engaging with socio-technical configurations. Area 39, 458-469. doi: $10.1111 / j .1475-4762.2007 .00772 . x$

Walker, G., Cass, N., Burningham, K., and Barnett, J. (2010). Renewable energy and sociotechnical change: imagined subjectivities of 'the public' and their implications. Environ. Plan. A 42, 931-947. doi: 10.1068/a41400

Watson, M. (2012). How theories of practice can inform transition to a decarbonised transport system. J. Trans. Geogr. 24, 488-496. doi: 10.1016/j.jtrangeo.2012.04.002

Wilkie, A., Michael, M., and Plummer-Fernandez, M. (2015). Speculative method and Twitter: bots, energy and three conceptual characters. Soc. Rev. 63, 79-101. doi: 10.1111/1467-954X.12168
Williams, L., Macnaghten, P., Davies, R., and Curtis, S. (2017). Framing 'fracking': exploring public perceptions of hydraulic fracturing in the United Kingdom. Public Underst. Sci. 26, 89-104. doi: 10.1177/09636625155 95159

Winner, L. (1986). The Whale and the Reactor: A Search for Limits in an Age of High Technology. Chicago: The University of Chicago Press.

Wynne, B. (1991). Knowledges in context. Sci. Technol. Hum. Valu. 16, 111-121. doi: $10.1177 / 016224399101600108$

Wynne, B. (1996). "May the sheep safely graze? A reflexive view of the expertlay knowledge divide," in Risk, Environment and Modernity: Towards a New Ecology, eds S. M. Lash, B. Szerszynski, and B. Wynne (London: Sage), 44-83.

Wynne, B. (2006a). "Afterword," in Governing at the Nanoscale, M. B. Kearnes, P. Macnaghten, and J. Wilsdon (London: Demos), 70-78.

Wynne, B. (2006b). Public engagement as a means of restoring public trust in science - hitting the notes, but missing the music? Comm. Genet. 9, 211-220. doi: 10.1159/000092659

Wynne, B. (2007). Public participation in science and technology: performing and obscuring a political-conceptual category mistake. East Asian Sci. Technol. Soc. Int. J. 1, 99-110. doi: 10.1007/s12280-007-9004-7

Yildiz, Ö., Rommel, J., Debor, S., Holstenkamp, L., Mey, F., Müller, J. R., et al. (2015). Renewable energy cooperatives as gatekeepers or facilitators? Recent developments in Germany and a multidisciplinary research agenda. Energy Res. Soc. Sci. 6, 59-73. doi: 10.1016/j.erss.2014.12.001

Conflict of Interest Statement: The authors declare that the research was conducted in the absence of any commercial or financial relationships that could be construed as a potential conflict of interest.

Copyright $\odot 2018$ Chilvers and Pallett. This is an open-access article distributed under the terms of the Creative Commons Attribution License (CC BY). The use, distribution or reproduction in other forums is permitted, provided the original author(s) and the copyright owner are credited and that the original publication in this journal is cited, in accordance with accepted academic practice. No use, distribution or reproduction is permitted which does not comply with these terms. 